\title{
HUBUNGAN MOTIVASI PERAWAT DENGAN KEPATUHAN PELAKSANAAN STANDAR PROSEDUR OPERASIONAL PENCEGAHAN RISIKO JATUH DI RUANG RAWAT INAP
}

\author{
Ahsan ${ }^{1}$, Niko Dima², Ni Luh Putu Ayu Prasiska ${ }^{3}$ \\ Program Studi Ilmu Keperawatan Fakultas Kedokteran Universitas Brawijaya \\ E-mail : ahsanfkub@yahoo.com
}

\begin{abstract}
Falling is a serious problem and makes high costs for patients and all health facilities. One of the factors that influenced the compliance of the Nurses in the implementation of the SPO (Operational Procedure Standard) is the motivation and perception of the Nurse toward their profession. The aim of the research is to find out the relationship between Nurses motivation and compliance with the implementation of the prevention risk proedure. This study was used a crosssectional design. The population used is all nursing staff in the inpatient ward of Kanjuruhan Hospital with purposivei sampling technique with a sample of 109. The study was conducted in February March 2018. Data collection used questionnaires about the characteristics of respondents, nurses' motivation and compliance with risk prevention procedure of fall down. Statistical analysis uses Ranki Spearman test. Presentation of data in the form of frequency tables distribution and narration. The results of the study were found that is significant relationship between motivation and compliance with the implementation of preventive SPO at risk of falling. The correlation (r) value is 0.424 which means that the relationship between the two variables are in the same direction, the higher the motivation, the compliance with the implementation of the preventive SPO become higher too. From the results of this study, a continuous socialization of SPO prevention is needed, and make motivated nurses to comply with the implementation of the SPO.
\end{abstract}

Keywords : Risk of falling, Standard Operating Procedure, Compliance, Motivation

Abstrak : Jatuh merupakan suatu masalah yang serius dan memerlukan biaya yang tinggi bagi pasien dan semua fasilitas kesehatan. Salah satu faktori yang mempengaruhi kepatuhani perawat dalam pelaksanaan SPO (Standar Prosedur Operasional) yaitu motivasi dan persepsi perawat terhadap pekerjaannya. Tujuan penelitian yaitu mengetahui adanya hubungan antara motivasi perawat dengan kepatuhan pelaksanaan SPO pencegahan risiko jatuh di ruang rawat inap. Penelitian ini menggunakan desain crossi sectional. Populasi yang digunakan yaitu seluruh tenaga keperawatan di ruang rawat inap RSUD Kanjuruhan dengan tehnik pengambilan sampel yaitu purposive sampling dengan jumlah sampel 109. Penelitian dilakukan pada bulan februari - maret 2018. Pengumpulan data menggunakan kuesioner tentang karakteristik responden, motivasi perawat dan kepatuhan pelaksanaan SPO pencegahan risiko jatuh. Analisis statistik menggunakani uji Rank Spearman. Penyajian data dalam bentuk tabel distribusi frekuensi dan narasi. Hasil penelitian yaitu terdapat hubungan yang signifikan antara motivasi perawat dengan kepatuhan pelaksanaan SPO pencegahan risiko jatuh. Besar korelasi ( $r$ ) yaitu 0,424 yangi artinya bentuk hubungan kedua variabel adalah searah yaitu semakin tinggi motivasi maka kepatuhan pelaksanaan SPO pencegahani risiko jatuh juga semakin tinggi. Dari hasil penelitian ini diperlukan sosialisasi secara terus menerus tentang SPO pencegahan resiko jatuh di ruang rawat inap dan memotivasi perawat terhadap kepatuhan pelaksanaan SPO.

Kata Kunci : Risiko jatuh, Standar Prosedur Operasional, Kepatuhan, Motivasi

\section{PENDAHULUAN}

Jatuh merupakan suatu masalah yang serius dan memerlukan biaya yang tinggi bagi pasien dan juga untuk semua fasilitas kesehatan (Rowe, 2012). World Health organization (WHO) menyatakan bahwa peluang terjadinya kecelakaan rumah sakit adalah 1 : 300 (WHO, 2005), sehingga menuntut pelayanan kesehatan, khususnya rumah sakit agar mengurangi masalah risiko cedera yang dialami pasien selaku pengguna jasa layanan. Kongres PERSI (Persatuan
Rumah Sakit Indonesia) XII di Jakarta pada tanggal 8 November 2012 melaporkan kejadian pasien jatuh di rumah sakit Indonesia pada bulan Januari sampai September 2012 sebanyak $14 \%$.

Hal tersebut membuat persentase pasien jatuh termasuk ke dalam lima insiden medis selain medicine error (Komariah, 2012). Laporan tahunan pada tahun 2012 yang disampaikan oleh Rumah Sakit Islam Malang diperoleh data bahwa kejadian jatuh masih 
menempati urutan keempat dari seluruh KTD (Unisma, 2012).

Kerugian yang diakibatkan dari insiden jatuh yaitu dapat menyebabkan kejadian yang tidak diharapkan, seperti kerusakan fisik dan psikologis dan juga berdampak bagi rumah sakit sendiri. Morse Fall Score (MFS) merupakan salah satu penilaian upaya pencegahan risiko jatuh yang merupakan salah satu prinsip dari kemampuan serta tingkah laku perawat dalam melakukan pekerjaan sesuai tugasnya yang berhubungan dengan kepatuhan pelaksanaan SPO (Setyarini \& Herlina, 2013).

Kepatuhan merupakan suatu bentuk perilaku. Beberapa faktor yang mempengaruhi kepatuhan perawat dalam melakukan SPO yaitu sikap seseorang, motivasi dan persepsi terhadap pekerjaannya (Natasia, Loekqijana \& Kurniawati, 2014). Motivasi merupakan salah satu hal penting untuk seseorang dalam melakukan perkerjaan dimana semakin motivasi seseorang meningkat maka kinerjanya semakin meningkat (Nur, Noor, \& Irwandi, 2013). Faktor yang membuat seorang perawat kurang memiliki motivasi kerja yaitu kurang puas terhadap pekerjaannya dan kurangnya insentif yang didapatkan.

Penelitian yang dilakukan oleh Natasia, Loekqijana dani Kurniawati (2014) menunjukan bahwa ada pengaruh yang signifikan antara motivasi dan persepsi terhadap kepatuhan perawat dalam pelaksanaan SPO. Namun, penelitian yang dilakukan oleh Mulyono Hamzah dan Abdullah (2013) menunjukan hal yang berbeda dengan menyatakan tidak ada pengaruh yang signifikan antara motivasi kerja dengan kinerjai. Hal ini mungkin dipengaruhi oleh beberapa faktor yang mempengaruhi motivasi antara lain karakteristik seseorang dan juga karakteristik pekerjaan.

Hasil laporan dari target dan realisasi penilaian akreditasi Rumah Sakit Umum Daerah (RSUD) Kanjuruhan Kabupaten Malang Tahun 2012 menyatakan bahwa penilaian standar keselamatan pasien pengurangan risiko pasien jatuh masih rendah, yaitu $27 \%$ dari target pencapaian $\geq 80 \%$ (RSUD Kanjuruhan, 2012). Hasil studi pendahuluan pada tanggal 3-8 Januari 2018 di RSUD Kanjuruhan dilaporkan bahwa pernah ada kejadian pasien jatuh salah satunya di ruang Diponegoro. Data yang di dapat dari tim Keselamatan Pasien Rumah Sakit (KPRS) RSUD Kanjuruhan, pada tahun 2013 tercatat 8 orang pasien jatuh dan pada tahun 2014 didapat 0 pasien jatuh. Setelah adanya program pencegahan pasien risiko jatuh yang diterbitkan pada tahun 2015, masih didapatkan angka kejadian jatuh pada tahun 2015 sebanyak 3 orang, pada tahun 2016 sebanyak 2 orang, dan pada tahun 2017 sebanyak 2 orang. Data pasien yang jatuh berasal dari pasien dewasa, selain itu dilakukan wawancara bersama kepala ruang di ruang Airlanga dan ruang Diponegoro didapatkan hasil di RSUD sudah adanya format asesmen dan intervensi pencegahan risiko jatuh dan sudah mempunyai SPO terkait pencegahan jatuh, namun dari 10 indikator penerapan SPO pencegahan risiko jatuh pasien, perawat di ruang Airlangga tidak merendahkan tempat tidur pasien yang berisiko jatuh, sedangkan di ruang Diponegoro perawat merendahkan tempat tidur pasien yang berisiko jatuh. Upayaupaya tersebut digambarkan perawat mempunyai kemampuan yang baik terkait pencegahan risiko jatuh, namun faktanya insiden jatuh di rumah sakit masih terjadi.

Berdasarkan uraian di atas, didapatkan bahwa belum sejalannya hasil penelitian mengenai motivasi perawat dalam pekerjaannya dan juga kurangnya kepatuhan perawat dalam pelaksanaan SPO pecegahan risiko pasien jatuh, oleh karena itu, peneliti tertarik untuk melakukan penelitian mengenai hubungan motivasi perawat dengan kepatuhan pelaksanaan standar prosedur operasional pencegahan risiko jatuh di ruang rawat inap.

\section{METODE PENELITIAN}

Metode yang digunakan yakni deskriptif analitik dengan pendekatan cross sectional. Pengambilan data dilakukan pada Februari - Maret 2018 di RSUD Kanjuruhan. Tempat yang digunakan dalam penelitian yaitu di ruang Airlanga, Brawijaya, Diponegoro, Imam Bonjol, Fatahillah, Gajah Mada dan Hasanudin. Populasi yang digunakan yaitu seluruh tenaga keperawatan di ruang rawat inap RSUD Kanjuruhan, dengan jumlah sampel 109 perawat dengan teknik sampling purposive sampling. Instrumen pengumpulan data terdiri dari 3 kuesioner antara laian karaktersitik responden, motivasi perawat dan kepatuhan pelaksaaan standar prosedur operasional pencegahan risiko jatuh. Untuk menganalisis hubungan antar variabel yaitu menggunakan uji Rank Spearman. Penyajian data hasil penelitian dalam bentuk tabel distribusi frekuensi dan narasi. 


\section{HASIL PENELITIAN}

Data hasil penelitian diuraikan dalam tabel distribusi frekuensi yaitu:

1. Usia Responden

Tabel 1. Distribusi Frekuensi Usia Responden

\begin{tabular}{lcccc}
\hline Karakteristik & Kategori & Frekuensi & Persentase (\%) \\
\hline Usia & $21-35$ tahun & 58 & 53,2 \\
& & $36-45$ tahun & 38 & 34,9 \\
& $>45$ tahun & 13 & 11,9 \\
& & 109 & 100 \\
\hline Jenis Kelamin & & 73 & 67,0 \\
& & Perempuan & 36 & 33,0 \\
& & Laki-Laki & 109 & 100 \\
\hline Pendidikan Terakhir & & D3 & 95 & 87,2 \\
& & D4 /S1 & 14 & 12,8 \\
& & & 109 & 100 \\
\hline Masa Kerja & & $1-5$ tahuni & 29 & 26,6 \\
& & $6-10$ tahuni & 24 & 22,0 \\
& & $>10$ tahuni & 56 & 51,4 \\
& & 109 & 100 \\
\hline
\end{tabular}

Tabel 1 menunjukan bahwa dari 109 orang yang menjadi responden pada penelitian ini, sebagian besar yaitu 58 responden $(52,2 \%)$ berusia $21-35$ tahun, 73 responden $(67,0 \%)$ adalah perempuan, 95 responden $(87,2 \%)$ memiliki pendidikan terakhir Diploma-III, dan 56 responden $(51,4 \%)$ memiliki masa kerja $>10$ tahun.

\section{Motivasi Perawat}

Tabel 2. Distribusi Frekuensi Motivasi Perawat

\begin{tabular}{ccc}
\hline Motivasi Perawat & Frekuensi & Persentase (\%) \\
\hline Baik & 63 & 57,8 \\
Cukup & 46 & 42,2 \\
Kurang & 0 & $0 \mathrm{i}$ \\
\hline Total & $\mathbf{1 0 9}$ & $\mathbf{1 0 0}$ \\
\hline
\end{tabular}

Berdasarkan tabel 2 menunjukan bahwa dari 109 orang yang menjadi sampel pada penelitian ini, sebagian besar yaitu 63 responden $(57,8 \%)$ memiliki motivasi yang baik dalam bekerja.

\section{Kepatuhan Pelaksanaan SPO Pencegahan Risiko Jatuh}

Tabel 3 Distribusi Frekuensi Kepatuhan Pelaksanaan SPO Pencegahan Risiko Jatuh

\begin{tabular}{cccc}
\hline No & $\begin{array}{c}\text { Kepatuhan Pelaksanaan SPO } \\
\text { Pencegahan Risiko Jatuh }\end{array}$ & Frekuensi & Persentase (\%) \\
\hline $\mathbf{1 .}$ & Patuh & 59 & 54,1 \\
2. & Cukup patuh & 50 & 45,9 \\
3. & Kurang patuh & 0 & 0 \\
\hline & Total & $\mathbf{1 0 9}$ & $\mathbf{1 0 0}$ \\
\hline
\end{tabular}

Berdasarkan tabel 3 di atas diketahui bahwa dari 109 orang yang menjadi sampel pada penelitian ini, sebagian besar yaitu 59 responden $(54,1 \%)$ diantaranya patuh dengan pelaksanaan standar prosedur operasional pencegahan risiko jatuh di ruang rawat inap RSUD Kanjuruhan. 


\section{Analisisi Bivariat}

Tabel 4. Hasil Cros tab antara motivasi perawat dengan kepatuhan pelaksanaan Standar Prosedur Operasional pencegahani risiko jatuh

\begin{tabular}{ccccccccc}
\hline & \multicolumn{9}{c}{ Tingkat Kepatuhan } & \multicolumn{2}{c}{ Jumlah } \\
\cline { 2 - 7 } Motivasi & \multicolumn{2}{c}{ Kurang } & \multicolumn{2}{c}{ Cukup Patuh } & \multicolumn{2}{c}{ Patuh } & Frekuensi & (F) \\
\cline { 2 - 7 } & Patuh & $\%$ & $F$ & $\%$ & $F$ & $\%$ & & (Persentase) \\
\hline Baik & 0 & 0 & 21 & 19,3 & 42 & 38,5 & 63 & 57,8 \\
Cukup & 0 & 0 & 29 & 26,6 & 17 & 15,6 & 46 & 42,2 \\
Kurang & 0 & 0 & 0 & 0 & 0 & 0 & 0 & $0 \%$ \\
\hline Total & 0 & 0,0 & 50 & 45,9 & 59 & 54,1 & 109 & $100 \%$ \\
\hline
\end{tabular}

Berdasarkan tabel di atas diketahui bahwa terdapat 42 responden $(38,5 \%)$ memiliki motivasi yang baik dan sudah patuh dengan pelaksanaan SPO pencegahan risiko jatuh di ruang rawat inap. Makna dari hasil penelitian ini yaitu perawat dengan motivasi yang baik memiliki kepatuhan pelaksanaan SPO pencegahan risiko jatuh yang baik pula.

\section{Hasil Uji Korelasi Rank Spearman}

Tabel 5. Pengujian Hubungan Antara Motivasi Perawat dengan Kepatuhan Pelaksanaan SPO Pencegahan Risiko Jatuh

\begin{tabular}{cccc}
\hline $\mathbf{R}_{\mathbf{x y}}$ & Signifikasi $(\boldsymbol{p}$-value $)$ & Keputusan & Arah hubungan \\
\hline 0,424 & 0,000 & Tolak $\mathrm{H}_{0}$ & $+($ searah $)$ \\
\hline
\end{tabular}

Pengujian hipotesis pada tabel di atas dengan menggunakan uji korelasi Rank Spearman dilakukan untuk mengetahui hubungan antara motivasi perawat dengan kepatuhan pelaksanaan standar prosedur operasional pencegahan risiko jatuh di ruang rawat inap yang bertempat di RSUD Kanjuruhan. Hasil uji korelasi rank spearman diketahui bahwa dengan nilai signifikansi 0,000 ( $p$-value < $0,05)$, maka $\mathrm{H}_{0}$ ditolak dan $\mathrm{H}_{1}$ diterima yang artinya terdapat hubungan yang signifikan

\section{PEMBAHASAN}

\section{Motivasi perawat}

Hasil penelitian dan analisis data yang telah dilakukan, didapatkan bahwa sebagian besar responden memiliki motivasi yang baik. Motivasi yang baik ini kemungkinan disebabkan karena perawat di RSUD Kanjuruhan bekerja sesuai dengan prosedur yang ada. Hal ini sejalan dengan penelitian yang pernah dilakukan oleh Budiono, Alamsyah dan Wahyu (2014) mengenai penerapan instrumen dan Standar Prosedur Operasional manajemen risiko pasien Jatuh menyatakan bahwa perawat di ruang rawat inap telah melaksanakan manajemen risiko pasien jatuh sesuai dengan pedoman dan Standar Prosedur Operasional (SPO) yang ditetapkan. Penelitian ini diperkuat dengan penelitian yang dilakukan Handayani, Ariani, dan Maemunah (2017) mengenai motivasi antara motivasi perawat dengan kepatuhan pelaksanaan SPO pencegahan risiko jatuh di ruang rawat inap. Besar korelasi ( $r$ ) adalah 0,424 yang artinya besarnya kontribusi motivasi perawat dengan kepatuhan pelaksanaan SPO pencegahan risiko jatuh sebesar 0,424 serta bentuk hubungan kedua variabel adalah searah yaitu semakin tinggi motivasi maka kepatuhan pelaksanaan SPO pencegahan risiko jatuh juga semakin tinggi.

perawat dengan pelaksanaan Standar Prosedur Operasional (SPO) assesmen nyeri ulang di ruang rawat inap dewasa rumah sakit Panti Waluya Sawahan Malang menunjukan bahwa hampir seluruh perawat mempunyai motivasi yang baik dalam melaksanakan SPO assesmen nyeri ulang, dan hanya sebagian kecil yang mempunyai motivasi kurang.

Motivasi yang dilihat dalam penelitian ini memiliki 3 indikator motivasi yaitu kebutuhan berprestasi, kebutuhan berafiliasi dan kebutuhan berkuasa. Berdasarkan indikator tersebut, maka terdapat beberapa analisa yang dapat dilihat. Sesuai dengan indikator motivasi perawat, motivasi yang diterima responden dalam kategori baik terutama pada indikator kebutuhan berprestasi. Kebutuhan prestasi tertinggi yang dimiliki responden mayoritas dalam bentuk 
tanggung jawab dan merasa puas dan bangga atas prestasi yang telah dicapai namun hal itu berbanding terbalik dengan parameter menerima saran dan kritikan orang lain yang memiliki kebutuhan prestasi terendah. Hal ini sesuai dengan teori yang diungkapkan MC. Chelland yang menyatakan jika seseorang memiliki need for achievement tinggi akan mempunyai performance yang lebih baik dari pada orang yang mempunyai need for achievement rendah.

Kebutuhan berprestasi berfokus pada keberhasilan penyelesaian tugas dan menyukai umpan balik dari pekerjaannya dari pada hubungan kekerabatan serta mencari pengaruh (Suarli dan Bahtiar, 2008). Penelitian ini sejalan dengan penelitian yang dilakukan oleh Inayah, Keliat \& Gayatri (2011) menyatakan bahwa perawat pelaksana rawat inap di rumah sakit di daerah Bogor lebih dari setengah memiliki kebutuhan prestasi, potensi tinggi untuk mencapai yang terbaik, mencapai keberhasilan sesuai standar, dan berjuang untuk kesuksesan. Perawat pelaksanan berkebutuhan berprestasi lebih menyukai adanya tantangan dalam bekerja dan menerima tanggung jawab pribadi atas kesuksesan dan kegagalannya. Dapat disimpulkan bahwa motivasi yang baik kemungkinan berasal dari kebutuhan prestasi yang tinggi.

Selain kebutuhan berprestasi, terdapat kebutuhan berafiliasi yang dimiliki respoden, dimana kebutuhan berafiliasi tertinggi terlihat pada parameter menghindari konflik yang mengarah pada selalu berusaha menggunakan musyawarah untuk menyelesaikan masalah dan kebutuhan afiliasi terendah terdapat pada parameter lebih suka dengan orang lain yang mengarah pada menyukai apa yang dikerjakan oleh orang lain. Hal ini sesuai dengan teori MC. Chellan yang menyatakan bahwa seseorang yang memiliki kebutuhan afiliasi tinggi akan selalu mencari orang lain dan mempertahankan hubungan yang telah dibina dengan orang lain, sedangkan seseorang yang memiliki afiliasi rendah akan canggung mencari hubungan dengan orang lain dan tidak bisa mempertahankan hubungan dengan orang lain (Nursalam, 2014).

Pada penelitian ini didapatkan dari 3 indikator motivasi berprestasi yang diungkapkan MC. Chelland kebutuhan kekuasaan menempati urutan yang paling bawah. Kebutuhan kekuasaan yang masih kurang dimiiki responden yaitu kurang memiliki kontrol. Menurut teori MC. Chelland seseorang yang memiliki kebutuhan kekuasaan akan mengontrol, mengendalikan, atau memerintah orang lain (Nursalam, 2014). Kebutuhan kekuasaan dapat mempengaruhi tingkah laku seseorang atau kelompok lain sesuai dengan keinginan individu tersebut, dimana seseorang yang memiliki tingkat kebutuhan kekuasaan tinggi cenderung berperilaku lebih tegas (Mangkunegara, 2009).

Motivasi yang dimiliki perawat pada penelitian ini dapat dihubungkan dengan beberapa karakteristik. Karakteristik yang pertama adalah usia. Dari hasil penelitian didapatkan sebagian besar responden berusia 21-35 tahun. Sebanyak 58 responden berusia 21-35 tahun yang merupakan usia dewasa muda dimana usia dewasa muda dimulai dari usia 18 tahun dan berakhir pada usia 35 sampai 40 tahun yang ditandai dengan adanya kemandirian secara finansial dan orang tua serta adanya rasa tanggung jawab terhadap tindakan-tindakan yang dilakukan (Lemme, 1985). Usia dewasa muda tergolong usia produktif untuk memilih dan mempersiapkan karir yang optimal sehingga dapat menjadi modal yang baik untuk pengembangan sumber daya perawat di rumah sakit yang lebih baik (Atwater \& Duffy, 2005).

Selain usia dapat dilihat dari jenis kelamin dimana pada penelitian ini sebagian besar responden dengan jenis kelamin perempuan. Hal ini sesuai dengan penelitian Robbins (2006) bahwa perempuan lebih patuh dalam menjalankan wewenangnya dari pada laki-laki, dikarenakan laki-laki memiliki sifat agresif dan sebuah pengharapan untuk sukses, namun perbedaan tersebut sangat kecil dimana laki-laki dan perempuan tidak ada perbedaan dalam melakukan pemecahan masalah, keterampilan analitis, motivasi, sosialitas, dan lain sebagainya. Hal ini diperkuat dengan penelitian Yanti dan Warsito (2013) dimana pekerjaan perawat lebih diminati oleh perempuan karena keperawatan masih identik dengan pekerjaan yang sesuai dengan sifat perempuan yang lebih sabar, lemah lembut, dan peduli kepada pasien yang dirawat.

Dalam penelitian ini karakteristik pendidikan terakhir, hampir semua responden memiliki pendidikan D3 keperawatan. Penelitian ini sejalan dengan penelitian yang dilakukan Sanjaya, Rosa dan Ulfa (2017) yang menyatakan bahwa perawat ruang rawat inap dan IGD di RS Pupuk Kaltim mayoritas berpendidikan Diploma III keperawatan, dengan demikian diharapkan bahwa perawat akan memberikan asuhan keperawatan dengan baik untuk keselamatan pasien.

Dalam penelitian ini dilihat dari karakteristik masa kerja perawat, sebagian besar responden lama bekerja diatas 10 tahun. salah satunya adalah masa kerja. Hal ini sejalan dengan penelitian Habibi (2005) yang menyebutkan bahwa ada karyawan dengan masa kerja yang relatif masih baru tetapi 
memiliki motivasi yang sangat tinggi sebagai ajang pembuktian kemampuan kerja, ada pula karyawan dengan masa kerja yang sangat lama bahkan menjelang berakhir juga memiliki motivasi yang tinggi pula, karena ingin mengakhiri kariernya dengan penuh kesan yang baik ataupun alasan lainnya.

Penelitian ini sesuai dengan teori dari Eswin yang mengemukakan bahwa motivasi merupakan suatu keahlian dalam mengarahkan pegawai dan organisasi agar dapat bekerja secara maksimal, sehingga sesuai dengan keinginan para pegawai dan dapat mencapai tujuan organisasi. Motivasi yang baik dalam suatu perusahaan dapat mempengaruhi produksi kerja, dimana motivasi yang baik mengarah pada seorang perawat yang bekerja harus menghadapi seorang pasien manusia. Pekerjaan dengan motivasi yang baik diharapkan dapat mengubah kebiasaan kerja di lingkungan kerja yang kurang baik dan dapat dilakukan menurut prosedur yang ada (Hasibuan, 2005).

\section{Kepatuhan Perawat}

Hasil penelitian diketahui bahwa sebagian besar responden memiliki kepatuhan patuh dalam pelaksanaan standar prosedur operasional pencegahan risiko jatuh di ruang rawat inap yang bertempat di RSUD Kanjuruhan. Hal ini disebabkan karena perawat telah melakukan penanda kewaspadaan pasien jatuh. Penelitian ini didukung oleh penelitian yang dilakukan Setryarini dan Herlina (2013) yang meneliti tentang kepatuhan perawat melaksanakan Standar Prosedur Operasional pencegahan risiko jatuh, hasil penelitian menyebutkan bahwa kepatuhan perawat melaksanakan pencegahan pasien jatuh dengan hasil ratarata $75 \%$ patuh melaksanakan, $25 \%$ tidak patuh melaksanakan dimana hampir seluruh responden patuh terkait pengkajian MFS, sebagian besar perawat patuh memasang gelang di pergelangan tangan, sebagian besar responden patuh meletakan tanda perngkajian jatuh, sebagian responden patuh melakukan penulisan pada white board, sebagian besar responden patuh megatur posisi tempat tidur, dan hampir seluruh responden patuh memasang pagar pengaman.

Perawat di beberapa ruang rawat inap RSUD Kanjuruhan menyatakan bahwa di ruang Imam Bonjol dan Erlangga atas tidak terdapat bel di ruangan. Hal ini tidak sesuai dengan penelitian yang dilakukan oleh Nugraheni, Widjanesa, Kurniawan dan Ekawati (2017) yang dilakukan di Ruang Nusa Indah RSUD Tugorejo Semarang menyatakan bahwa kondisi sarana tidak berpengaruh terhadap pencegahan pasien jatuh, hal tersebut dikarenakan perawat yang melakukan pencegahan pasien jatuh menjawab bahwa sering membiarkan pagar penyangga tempat tidur pasien terbuka dan tidak melakukan penutupan pagar penyangga ketika melakukan pengecekan rutin di kamar tidur pasien.

Kepatuhan yang dimiliki perawat pada penelitian ini dapat dihubungkan dengan karakteristik. Karakteristik yang pertama adalah usia. Hasil penelitian menunjukan sebagian responden berusia 21-35 dimana usia tersebut tergolong usia dewasa muda (1840 tahun). Penelitian yang dilakukan oleh Ariastuti, Margawati, dan Wahyu Hidayati (2013) kategori umur usia muda ini mampu menyesuaikan di lingkungan pekerjaan yang baru, bersemangat dan berpeluang mengembangkan kinerja secara optimal dalam mengaplikasikan ilmu pengetahuan dan keterampilan. Dilihat dari karakteristik jenis kelamin hampir semua respoden dengan jenis kelamin perempuan. Hal ini sejalan dengan penelitian yang dilakukan oleh Prasetyo \& Hartanti (2017) yang hampir semua perawat di RSUD Kanjuruhan berjenis kelamin perempuan, dimana perempuan dapat lebih baik dalam mengupayakan keselamatan pasien dibanding dengan laki-laki.

Dilihat dari pendidikan terakhir, hampir semua pendidikan responden Diploma-III. Perawat dengan pendidikan Diploma-III keperawatan yang cukup baik akan melakukan praktik keperawatan yang efektif dan efisien yang selanjutnya akan menghasilkan pelayanan kesehatan yang bermutu tinggi. Tingkat pendidikan yang cukup akan memberikan kontribusi terhadap praktik keperawatan, dimana tingkat pendidikan seorang perawat akan mempengaruhi dasar pemikiran dibalik penerapan standar keperawatan (Suparna, 2015).

Dilihat dari masa kerja sebagian besar perawat memiliki masa kerja lebih dari 10 tahun. Menurut penelitian yang dilakukan oleh Suparna (2015) mengatakan lama masa bekerja seseorang dapat meningkatkan pengetahuan dan pengalaman yang dimiliki seorang perawat, hal ini dapat membantu dalam meningkatkan kinerja seseorang.

Pada penelitian ini perawat di RSUD Kanjuruhan dapat dikategorikan sebagian besar patuh terhadap standar prosedur operasional pencegahan risiko jatuh salah satunya dengan menggunakan penanda kewaspadaan jatuh. Hal ini dibuktikan dengan sebagian besar perawat yang telah melakukan standar prosedur operasional pencegahan risiko jatuh menggunakan pemasangan penanda kewaspadaan jatuh di ruangan ketika terdapat pasien yang bersiko untuk jatuh di ruang rawat inap dewasa. Hal ini sesuai dengan teori compliance yang dikembangkan 
oleh Green dan Kreuters (1991) yang menyatakan kepatuhan merupakan ketaatan melakukan sesuatu yang dianjurkan atau respon yang diberikan terhadap sesuatu di luar subjek. Penelitian sejalan dengan penelitian yang dilakukan Setyarini dan Herlina (2013), menjelaskan bahwa perawat sebagian besar responden patuh untuk melakukan pemasangan label segitiga, namun menurut analisa peneliti beberapa perawat masih kurang memilki kesadaran tentang pentingnya pemasangan label segitiga dan terdapat beberapa faktor yang menyebabkan adanya perawat belum melakukan pemasangan segitiga dengan baik yaitu faktor kesibukan atau mobilitas yang tinggi.

Dalam penelitian ini didapatkan juga hasil bahwa beberapa indikator seperti penilaian assesmen risiko jatuh di ruang rawat inap, assesmen ulang pasien yang berisiko jatuh dan pelepasan gelang terkait dengan pasien yang sudah tidak berisiko jatuh masih berada pada posisi yang paling bawah dibandingkan dengan indikator lainnya. Hal ini sesuai dengan faktor pemungkin (enabling factors) kepatuhan di mana faktor pemungkin dapat diartikan faktor pencetus terhadap perilaku yang dapat memungkinkan harapan dan tujuan terlaksana termasuk kemampuan dan sumber daya yang diperlukan untuk suatu perilaku.

Penelitian ini tidak sesuai dengan penelitian yang dilakukan oleh Setyarini dan Herlina (2013), menjelaskan bahwa perawat yang sudah mendapatkan sosialisasi atau memahami terkait dengan pengkajian risiko jatuh berdasarkan skala Morse cenderung lebih baik dalam melakukan pengkajian risiko jatuh dibandingkan dengan perawat yang belum memahami dan mendapat sosialisasi standar prosedur operasional pencegahan risiko jatuh, selain itu usia juga mempengaruhi kepatuhan perawat dalam menerapkan skala morse. Seseorang yang dikatakan senior lebih cenderung memiliki sikap yang kurang dalam pengkajian risiko jatuh menggunakan skala morse. Mereka lebih sering menggunakan penilaian berdasarkan ketergantungan pasien.

\section{Hubungan Motivasi Perawat dengan Kepatuhan Pelaksanaan Standar Prosedur Operasional Pencegahan Risiko Jatuh di Ruang Rawat Inap \\ Hasil crosstab diketahui bahwa} sebagian responden mempunyai motivasi yang baik dengan kepatuhan yang sudah patuh. Dalam penelitian ini terdapat hubungan yang signifikan antara motivasi perawat dengan kepatuhan pelaksanaan standar prosedur operasional pencegahan risiko jatuh di ruang rawat inap yang bertempat di RSUD Kanjuruhan. Hasil penelitian ini juga diperkuat oleh penelitian yang dilakukan oleh Natasia, Loekqijana, dan Kurniawati (2014) yang menyatakan bahwa faktor motivasi dan persepsi mempengaruhi kepatuhan perawat dalam pelaksanan asuhan keperawatan yang sesuai dengan SOP.

Pada penelitian ini motivasi dengan kepatuhan pelaksanaan standar prosedur operasional pencegahan risiko jatuh memiliki hubungan yang signifikan. Hasil analisis peneliti hal tersebut disebabkan karena mayoritas perawat di RSUD Kanjuruhan sudah memiliki kebutuhan prestasi yang tinggi dan sudah melakukan pemasangan penanda risiko pasien jatuh yang digunakan untuk mengurangi pasien jatuh.

Perawat sudah memiiki motivasi yang baik mengenai pengurangan pasien jatuh, namun masih didapatkan perawat yang memiliki motivasi yang cukup, sehingga pada pelaksanaan pengkajian risiko jatuh masih ada beberapa yang belum dilaksanakan. Penelitian serupa juga dilakukan oleh Badi'ah (2009) didapatkan hasil bahwa secara umum faktor motivasi mempunyai hubungan yang kuat dengan kinerja, sehingga dapat diprediksikan bahwa bahwa bila motivasi meningkat maka kinerja perawat akan meningkat.

Adanya hubungan antara motivasi dengan kepatuhan perawat dalam pelaksanaan standar prosedur operasional pencegahan risiko jatuh pasien dapat diasumsikan bahwa seseorang yang memiliki motivasi yang baik cenderung lebih baik dalam mengurangi pasien jatuh yang lebih baik dibandingkan dengan perawat yang memiliki motivasi cukup atau rendah. Motivasi perawat yang baik akan mempengaruhi tingkat kepatuhan perawat sehingga mengurangi risiko jatuh pada pasien. Pengkajian risiko jatuh ini telah dapat dilaksanakan sejak pasien masuk ke dalam ruangan, yaitu dengan menggunakan skala jatuh. Pengalaman, Pengetahuan dan sumber informasi merupakan hal yang mempengaruhi kejelian perawat dalam melakukan pengkajian risiko jatuh, sumber informasi disini dapat dalam pelatihan-pelatihan, seminar ataupun workshop mengenai risiko pasien jatuh. Dalam pelatihan-pelatihan perawat dibekali ilmu, skil dan pengalaman terkait Patient Safety (Anwar, Irwandy dan Noor 2012).

Kepatuhan muncul sebagai bentuk dari sikap. Apabila perawat memiliki sifat yang baik maka akan termotivasi untuk mematuhi tindakan yang berkaitan dengan tindakan pencegahan risiko jatuh (Sarwono, 2011). Hariandja (2009) juga berpendapat bahwa motivasi merupakan kekuatan yang mendorong perawat untuk melakukan pekerjaan. Terdapat dua faktor yang 
mempengaruhi adanya motivasi perawat yaitu faktor ekstrinsik dan intrinsik.

Faktor intrinsik muncul dalam diri yang dapat membangkitkan motivasi perawat, sebagai contoh kesadaran diri perawat dalam melaksanakan assesmen risiko jatuh. Sedangkan motivasi ekstrinsik berkaitan dengan faktor di luar individu seperti hubungan antar rekan kerja, hubungan dengan atasan, serta reward dan punishment (Markuis \& Huston, 2010).

Hubungan antar rekan kerja didapatkan apabila adanya kerjasama tim yang baik, saling mendukung satu sama lain dan

\section{KESIMPULAN DAN SARAN}

\section{Kesimpulan}

Terdapat hubungan yang signifikan antara motivasi perawat dengan kepatuhan pelaksanaan SPO pencegahan risiko jatuh di ruang rawat inap yang bertempat di RSUD Kanjuruhan.

\section{Saran}

\section{a. Bagi Rumah Sakit Umum Daerah Kanjuruhan}

Diharapkan Rumah sakit untuk melakukan sosialisasi kepada seluruh perawat yang berkaitan dengan pengkajian risiko jatuh salah satunya dengan skala Morse beserta bagaimana cara pengisian menggunakan form pengkajian risiko jatuh skala morse serta menentukan interpretasi secara benar dan mensosialisasikan standar prosedur operasional pencegahan risiko jatuh yang ada di rumah sakit tersebut yang berkaitan dengan penilaian risiko jatuh, assesmen ulang pasien yang berisiko jatuh, dan pelepasan gelang terkait pasien yang sudah tidak berisiko untuk jatuh. Sarana pendukung dalam mendukung kepatuhan perawat juga perlu diperhatian agar perawat dapat menjalankan standar prosedur operasional pencegahan risiko jatuh dengan maksimal salah satunya adanya bel disetiap ruangan. Selain itu bagi perawat di RSUD Kanjuruhan hendaknya dapat lebih meningkatkan dan mempertahankan motivasi dalam bekerja sehingga dapat memberikan pelayanan yang terbaik dan dapat berpengaruh pada kepatuhan perawat dalam

\section{DAFTAR PUSTAKA}

Anwar, A. Irwandy, dan Noor N.B. Hubungan Pengetahuan, Motivasi dan Supervisi dengan Kinerja Perawat dalam Melaksanakan Patient Safety di RSUP Dr. Wahidin Sudiruhusodo tahun 2012. saling melengkapi. Hubungan dengan atasan timbul ketika pimpinan memberikan pengarahan, bimbingan, memotivasi, dan memberikan dukungan (Hasibuan, 2008). Hal ini didukung dengan penelitian yang dilakukan oleh Febrianti, Musadieq dan Prasetya (2014) yang menyatakan bahwa pemberian reward dan punishment lebih dominan berpengaruh secara langsung terhadap kinerja karyawan dari pada motivasi kerja. Adanya motivasi, reward dan punishment yang diberikan oleh pimpinan diharapkan dapat merubah perilaku perawat untuk lebih mematuhi pekerjaannya.

pelaksanaan standar prosedur operasional pencegahan risiko jatuh agar nantinya perawat dapat mengurangi angka kejadian jatuh, sehingga dapat meningkatkan mutu pelayanan keperawatan yang nantinya berkaitan dengan meningkatnya akreditasi rumah sakit.

\section{b. Bagi institusi pendidikan}

Diharapkan hasil dari penelitian ini sebagai bahan acuan dalam menentukan kebijakan dalam melakukan penyusunan panduan perkuliahan utamanya berkaitan dengan motivasi perawat dengan kepatuhan pelaksanaan SPO pencegahan risiko jatuh, agar ketika mahasiswa praktek di lapangan dapat mengetahui teori motivasi dan juga pelaksanaan interpretasi pencegahan risiko jatuh di rumah sakit agar perawat yang telah lulus dari institusi dapat meningkatkan dan engutamakan pelayanan dan pengabdian terbaik untuk pasien.

\section{c. Bagi peneliti}

Bagi peneliti selanjutnya dapat menerapkan teori ke dalam kegiatan nyata dilapangan terutama penerapan metode menggunakan metode observasi maupun wawancara agar peneliti melihat langsung kegiatan perawat pada saat memberikan pelayanan keselamatan pada pasien utamanya berkaitan dengan motivasi perawat yang hubungannya dengan kepatuhan pelaksanaan standar prosedur operasional pencegahan risiko jatuh dan mendapatkan data penelian yang akurat.
Skripsi tidak diketahui. Bagian Manajemen Rumah Sakit Fakultas Kesehatan Masyarakat : Universitass Hasanuddin. 
Ariastuti, Ni Luh Putu, Margawati A., Hidayati W. (2013). Analisis Faktor-Faktor yang Mempengaruhi Perawat dalam Melaksanakan Patient Safety di Kamar Bedah RS Telogorejo Semarang.

Atwater, E. \& Duffy, K.G. (2005). Psychology for Living : Adjustment, Growth, and Behavior Today. (8 $\left.{ }^{\text {th }} \mathrm{Ed}\right)$. New Jersey : Prentice Hall.

Badi'ah A., Mendri N.K., Ratna W., Hendarsih S. (2009). Hubungan Motivasi Perawat dengan Kinerja Perawat di ruang Inap Rumah Sakit Daerah Panembahan Senopati Bantul Tahun 2008. Jurnal Manajemen Pelayanan Kesehatan Volume12, No. 2, Halaman 74-82.

Budiono, S., Alamsyah, A., Wahyu Tri, S. (2014). Pelaksanaan Program Manajemen Pasien dengan Risiko Jatuh di Rumah Sakit. Jurnal Kedokteran Brawijaya, Vol. 28, Suplemen No.1, 2014. Program Studi Magister Manajemen Rumah Sakit Fakultas Kedokteran Unversitas Brawijaya Malang.

Habibi, B. (2005) Faktor-faktor yang Mempengaruhi Motivasi Kerja Karyawan di PT.Askes Regional VI Jawa Tengah dan D.I.Y bagian Sumber Daya Manusia dan Umum Semarang. Diakses pada web Lib.unnes.ac.id.http:lib.unenes.ac.id/40 8/1/1102.pdf. Diakses pada 4 April 2018.

Handayani, S.U., Ariani N.L., Maemunah Neni. ( 2017). Hubungan Antara Pengetahuan dan Motivasi perawat dengan Pelaksanaan Standar Prosedur Operasionak (SPO) Assesment Nyeri Ulang di Ruang Rawat Inap Dewasa Rumah Sakit Panti Waluya Sawahan Malang. Nursing News Volume 2, Nomor 3, 2017.

Hariandja M. (2009).Manajemen Sumber Daya Manusia. Jakarta: Grasindo

Hasibuan, M.S.P. (2006). Manajemen Sumber Daya Manusia. Jakarta : PT. Bumi Aksara

Hasibuan, M.S.P. (2008). Organisasi dan Motivasi Dasar Peningkatan Produktivitas. Jakarta : PT. Bumi Aksara

Inayah,I., Keliat, B.A. \& Gayatri, D. (2011). Motivasi Kerja Meningkatkan Manajeman Waktu Perawat. Jurnal Keperawatan Indonesia, Volume14, No.2, Juli 2011.

Komariah, Siti. (2012). Peran Keperawatan dalam Menurunkan Insiden
Keselamatan Pasien. Kongres XII PERSI: Jakarta.

Markuis \& Huston. 2010. Kepeminpinan dan Manajemen Keperawatan : Teori dan Aplikasi Edisi 4. Jakarta : Grasindo.

Mulyono, M.H., Hamzah A., Abdullah Z. (2013). Faktor-Faktor yang Berpengaruh Terhadap Kinerja Perawat di Rumah Sakit Tingkat III 16.06.01 Ambon. Jurnal AKK 2 (1): Hal. 10-26.

Natasia Nazvia, Loekqijana Ahas, Kurniawari Janik. (2014). Faktor yang Mempengaruhi Kepatuhan Pelaksanaan SOP Asuhan Keperawatan di ICU- ICCU RSUD Gambiran Kota Kediri. Jurnal Kedokteran Brawijaya, Vol.28, Suplemen No. 1, 2014.

Nugraheni, M., Widjasena B., Kurniawan B. Ekawati. (2017). Faktor - Faktor yang Berhubungan dengan Pencegahan Jatuh pada Pasien Risiko Jatuh Oleh Perawat di Ruang Nusa Indah RSUD Tugurejo Semarang. Jurnal Kesehatan Masyarakat (e-Journal) Volume 5, Nomor 2, April 2017. ISSN: 23563346.

Nur, Qalbia Muhammad, Noor H.N.B., Irwandi. (2013). Hubungan Motivasi dan Supervisi Terhadap Kinerja Perawat Pelaksana dalam Menerapkan Patient Safety di Rawat Inap RS Universitas Hasanuddin Tahun 2013. Jurnal Manajemen Rumah Sakit: Unhas Makasar.

Nursalam. (2014). Manajemen Keperawatan Aplikasi dalam Praktik Keperawatan Profesional, Ed. 4 . Jakarta: Salemba Medika.

Oktaviani, H., Sulisetyawati S. Dwi, Fitriana R.Nur. 2015. Hubungan Pengetahuan dengan Kepatuhan Perawat dalam Pelaksanaan Standar Prosedur Operasional Pencegahan Risiko Jatuh Pasien di Rumah Sakit Panti Waluyo Surakarta. Skripsi di publikasikan.Program Srudi S1 Keperawatan : Stikes Kusuma Husada Surakarta.

Robbins, S.P. (2006). Perilaku Organisasi. Jakarta: PT. Indeks Kelompok Gramedia

Rowe, Jimmi. (2012). Preventing Patient Falls: What Are The Factors in Hospital Setting That Help Reduce and Prevent Inpatient Falls ?. Home Health Care Management \& Practice, 25 (3), Hal. 98-103.

RSUD, Kanjuruhan. (2012). Target dan Realisasi Penilaian Akreditasi Rumah 
Sakit Umum Daerah Kanjuruhan Kabupaten Malang Tahun 2012. Diakses pada web. http: http://rsudkanjuruhan.malangkab.go.id/konten61.html.

Sanjaya, P.D., Rosa, E.M., Ulfa Maria. (2017). Evaluasi Penerapan Pencegahan Pasien Berisiko Jatuh di Rumah Sakit. Kes Mas: Jurnal Fakultas Kesehatan Masyarakat, Volume 11, Issue 2, September 2017, pp. 107-115. ISSN: 1978-0575

Sarwono. (2011). Manajemen Sumber Daya Manusia di Rumah Sakit Suatu Pendekatan Sistem. Jakarta : EGC

Setyarini E.A, dan Herlina Lusiana Lina. (2013). Kepatuhan Perawat Melaksanakan Standar Prosedur Operasional : Pencegahan Pasien Risiko Jatuh di Gedung Yosef 3 Dago dan Surya Kencana Rumah Sakit Boorromeus. Jurnal Kesehatan STIKES Santo Boorromeus: Bandung.

Suarli S., dan Bahtiar, Y. (2008). Manajemen Keperawatan: dengan pendekatan praktis. Jakarta: Penerbit Erlangga.
Suparna. (2015). Evaluasi Penerapan Patient Safety Risiko Jatuh Unit Gawat Darurat di Rumah Sakit Panti Rini Kalasan Sleman. Naskah Publikasi. Program Studi Ilmu Keperawatan : Sekolah TInggi Kesehatan 'Aisyiyah Yogyakarta.

Unisma, Rumah Sakit Islam Malang. (2012). Laporan Tahunan Rumah Sakit Islam Unisma Malang Tahun 2012. Malang: Rumah Sakit Islam Unisma Malang.

WHO, World Health Organization. (2005). World Allance for Patient Safety and WHO Guidelines on Hand Hygiene in Health Care ( adcanced draft): $A$ Summary Cleans hands. Diakses pada web. www.who.int/patientsafety.

Yanti, R.I \& Warsito, B.E. (2013). Hubungan Karakteristik Perawat, Motivasi, dan Supervisi dengan Kualitas Dokumentasi Proses Asuhan Keperawatan. Jurnal Managemen Jurusan Keperawatan Fakultas Kedokteran Universitas Diponegoro: Semarang. 